\title{
Divastartalmú oxidoreduktázok szerkezeti és funkcionális modelljei
}

\author{
SZÁVULY Miklós István ${ }^{\mathrm{a}}$, LAKK-BOGÁTH Dóra ${ }^{\mathrm{a}}$, CSONKA Róbert ${ }^{\mathrm{a}}$, TURCAS Ramona ${ }^{\mathrm{a}}$, \\ SPEIER Gábor ${ }^{\mathrm{a}}$ és KAIZER József ${ }^{\mathrm{a}}{ }^{*}$
}

${ }^{a}$ PE Kémia Intézet, Bioszerves és Biokoordinációs Kémiai Kutatócsoport, Egyetem utca 8., 8200 Veszprém, Magyarország

A triplett-állapotú dioxigén két pártalan elektronnal rendelkezik, stabilis és ezért szingulett-állapotú szerves szubsztrátumokkal szemben inert. A lényegesen nagyobb energiatartalmú, instabilabb szingulett-állapotú dioxigén reaktivitása nagyobb és redoxireakciókban, valamint elektrociklikus reakciókban (pl. olefinekkel, Diels-Aldertípusú reakciókban) jól reagál. A dioxigénnek a redoxireakciókban mutatott viszonylagos inertsége az első elektron termodinamikailag kedvezőtlen felvételével is magyarázható $\left(E^{0}=-0,32 \mathrm{~V}\right)$. A spin-tiltott folyamat tehát a dioxigén fotooxidációs, illetve átmenetifémekkel történő oxidatív-addíciós reakciójával oldható fel.

A dioxigént felhasználó metalloenzimek (oxidoreduktázok) és szintetikus modelljeik kapcsán az elsődleges kérdés, hogy a dioxigén aktiválása milyen módon, milyen lépéseken keresztül valósul meg. Ennek megértésében sokat segíthet az intermedier-kutatás, amelynek feladata, hogy az enzimfolyamatokban és az azokat modellező bioutánzó rendszerekben a reaktív intermedierek elkülönítésén és spektroszkópiai jellemzésén keresztül információt nyújtson a dioxigén- és rajta keresztül a szubsztrátaktiválás mechanizmusáról. A vastartalmú oxidoreduktázok az aktív centrumban lévő fémionok száma szerint egy- illetve kétmagvú, a fémek koordinációs övezete alapján pedig hem-típusú és nem-hem-típusú csoportra oszthatóak. A hem-típusú enzimekben a vasiont a porfirinligandum övezi, míg a nem-hem-típusú enzimekben a vasiontartalmú kavitás két jellegzetes aminosavrészből; hisztidinből és egy savas (aszparaginsav, glutaminsav) egységből épül fel. Utóbbiak igen változatos módon, egy-, illetve kétfogú, valamint terminális és hídhelyzetü ligandumként is részt vehetnek a komplexképzésben. ${ }^{1}$ A termodinamikailag inert dioxigénmolekula aktiválását reaktív peroxo- és oxo-intermedierek képződésén keresztül képzelik el, amelyek reakciója a megfelelö szubsztrátum molekulával már könnyen értelmezhető (1. ábra).<smiles>OO[Te]F</smiles>

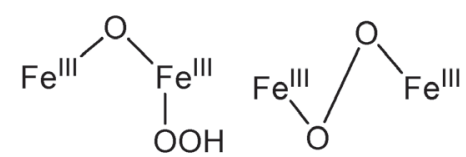<smiles>O=[Fe]</smiles>

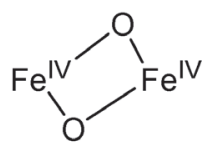

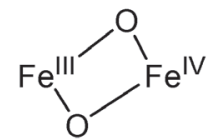

1. Ábra. Vastartalmú enzimek reaktív intermedierjei
A nem-hem-típusú divastartartalmú enzimek funkciójukat tekintve igen változatos kémiai reakciókért felelősek. Ide sorolható pl. a ribonukleotid reduktáz (R2), a sztearil-ACP $\Delta^{9}$ deszaturáz $\left(\Delta^{9} \mathrm{D}, \mathrm{ACP}=\right.$ acilhordozó fehérje), az oldható metán-monooxigenáz (sMMO), a human deoxihipuszin hidroxiláz (hDOHH) és a hemeritrin $(\mathrm{Hr})(2 . \dot{A} b r a)^{2}$

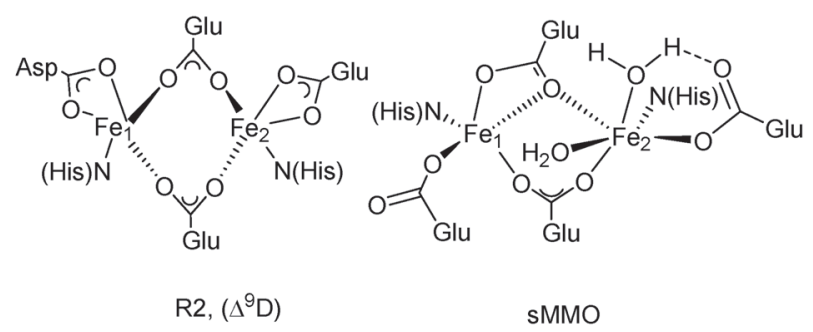

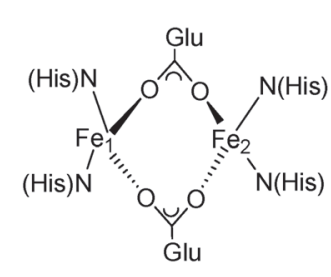

$\mathrm{hDOHH}$

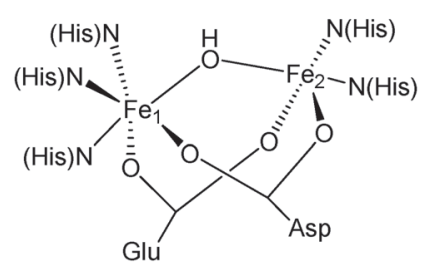

$\mathrm{Hr}$
2. Ábra. Néhány divas(II)tartalmú enzim aktív centruma.

Az R2 enzimet Escherichia coli és Salmonella typhimurium baktériumokból izolálták. Utóbbi esetében az aktív centrum röntgendiffrakciós szerkezetét is sikerült meghatározni. Ezen enzimek a DNS szintézishez elengedhetetlen dezoxi-ribonukleotidokat állítják elő a ribonukleotidok redukciójával. Ezen folyamat a reakcióban nélkülözhetetlen tirozil gyök kialakításán keresztül értelmezhető. ${ }^{3} \mathrm{~A} \Delta^{9} \mathrm{D}$ enzimek segítségével a sztearinsav cisz-helyzetü kettőskötést $\left(\mathrm{C}^{9}=\mathrm{C}^{10}\right)$ tartalmazó telítetlen zsírsavvá, olajsavvá alakul át, ${ }^{4}$ míg a metanotróf baktériumokban (Methylococcus capsulatus, Methylosinus trichosporium) található sMMO enzim a metán metanollá történő szelektív oxidációját katalizálja. ${ }^{5,6} \mathrm{~A}$ hDOHH enzim a hipuszin szintézisében vesz részt. A legújabb kutatások azt sejtetik, hogy az enzimnek és az általa katalizált folyamatoknak a megértése nagyban hozzájárulhat új antitumor és anti-HIV-1 terápiák kidolgozásához. ${ }^{7,8} \mathrm{~A} \mathrm{Hr}$ a dioxigén reverzibilis megkötésében játszik szerepet (3. Ábra). ${ }^{9,10}$ 


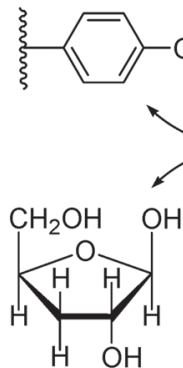<smiles>CCCC(=O)S[Mg]C(=O)O</smiles>

$$
\mathrm{CH}_{4} \stackrel{\mathrm{O}_{2}}{\stackrel{\mathrm{sMMO}}{\longrightarrow}}
$$

$\mathrm{CH}_{3} \mathrm{OH}$
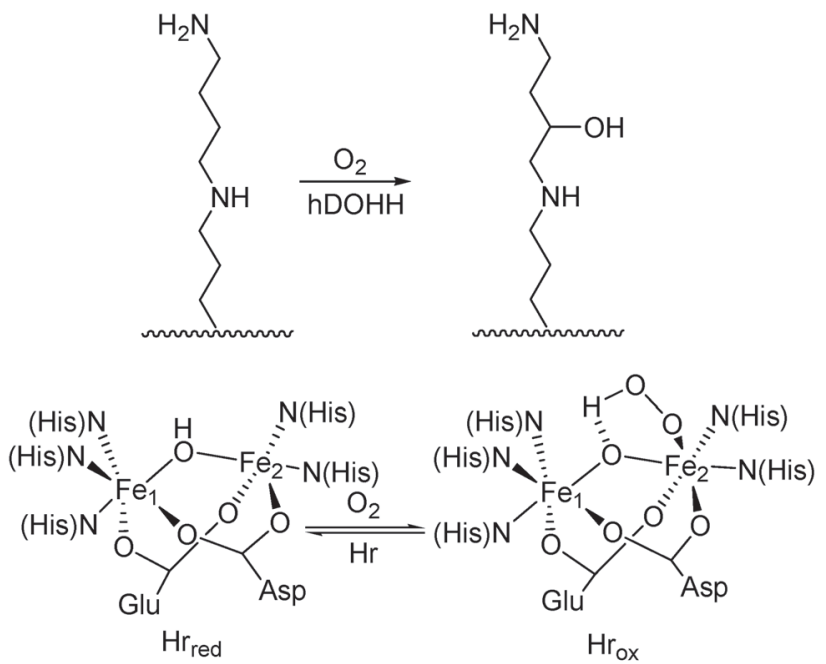

3. Ábra. Néhány divas(II)tartalmú enzim által katalizált reakció

A fenti enzimek redukált formája dioxigénnel metastabilis intermediereket eredményez, amelyek szerkezetét UV-vis, rezonancia-raman és némely esetben röntgendiffrakciós mérésekkel (EXAFS, X-ray) igazolták. ${ }^{2}$ Ezen eredmények alapján az oxidált forma a $\mathrm{Hr}$ enzim esetében egy $\mathrm{Fe}^{\mathrm{III}}\left(\mu-\mathrm{O}_{2} \mathrm{R}\right)_{2}(\mu-\mathrm{O}) \mathrm{Fe}^{\mathrm{III}} \mathrm{OOH}$, míg az R2 (élettartam: 2,7 perc), $\Delta^{9} \mathrm{D}(30$ perc), sMMO (1 s) és hDOHH enzimek esetében egy $\mathrm{Fe}^{\mathrm{III}}\left(\mu-\mathrm{O}_{2}\right) \mathrm{Fe}^{\mathrm{III}}$ szerkezetü peroxidhoz (P) vezet (3-4. Ábra). Az UV-vis spektrum 5-800 nm tartományában megjelenő elnyelések az $\mathrm{O}_{2}{ }^{2-} \rightarrow \mathrm{Fe}^{\mathrm{III}}$ töltésátvitelhez $(\mathrm{CT})$, a rezonancia-raman spektrum $8-900 \quad \mathrm{~cm}^{-1}$ tartományában megjelenő rezgések pedig a peroxid $v(\mathrm{O}-\mathrm{O})$ rezgéséhez rendelhetők. Az EXAFS mérések az első koordinációs övezetben uralkodó viszonyokat (kötéstávolságokat) írják le, beleértve a Fe Fe távolságokat. Az így kialakult intermedierek egyfajta puffer szerepet töltenek be, az adott szubsztrátum reakciója a belölük levezethető reaktív, magas vegyértékü $\mu$-oxo komponensekhez (X, Q) köthetőek. A hDOHH esetében a képződő $\mathrm{hDOHH}_{\text {peroxo }}$ enzim stabilitása lehetővé tette a röntgendiffrakciós szerkezetének a meghatározását $(5 . \text { Ábra })^{7}$

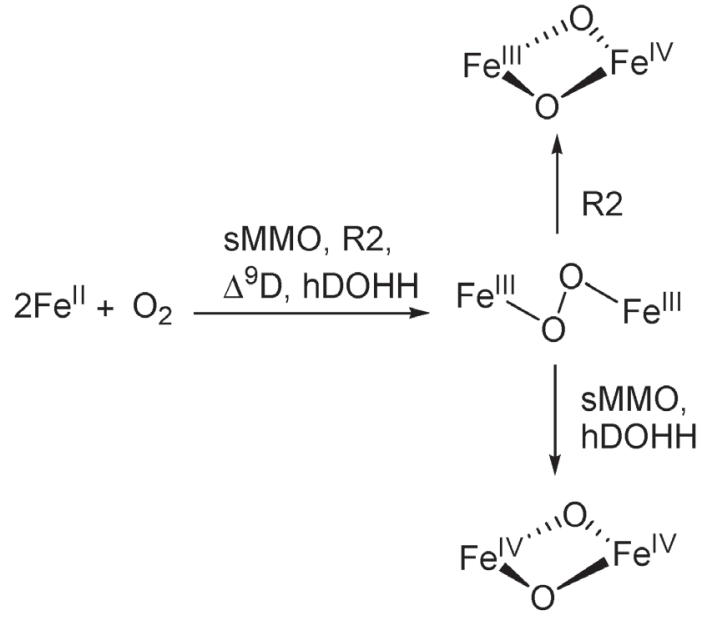

4. Ábra. Divas(II)tartalmú enzimek reaktív intermedierjei

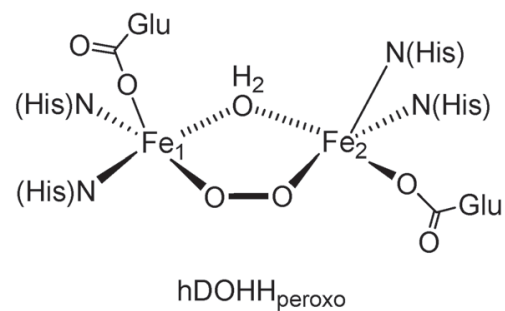

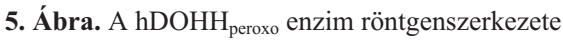

A nagyfokú stabillitás (1-2 nap szobahőmérsékleten) a fémionok környezetében fellelhetö nagyszámú hisztidinnek, valamint a karboxilátok terminális helyzetével magyarázható.

Az irodalomban számos peroxo-divas(III) szerkezet található, melyek az előbbiekben ismertetett enzimek szerkezeti modelljeinek tekinthetőek. Ezen komplexek jól megválasztott ligandumokkal képzett prekurzor vegyületek felhasználásával készültek dioxigén és/vagy $\mathrm{H}_{2} \mathrm{O}_{2}$ hatására. Az elöállitásukhoz vas(II), vas(III), egy és kétmagvú komplexek is felhasználhatóak. Ezekben többnyire $N$-donoratomot tartalmazó, polipiridil-típusú ligandumokat találhatunk.

$\mathrm{Az}$ eddig ismert peroxo-divas(III) komplexek igen változatos szerkezetekkel írhatóak le: $\mathrm{Fe}^{\mathrm{III}}\left(\mu-\mathrm{O}_{2}\right) \mathrm{Fe}^{\mathrm{IIII}}$; $\mathrm{Fe}^{\mathrm{III}}(\mu-\mathrm{O})\left(\mu-\mathrm{O}_{2}\right) \mathrm{Fe}^{\mathrm{III}}, \quad \mathrm{Fe}^{\mathrm{III}}(\mu-\mathrm{OH})\left(\mu-\mathrm{O}_{2}\right) \mathrm{Fe}^{\mathrm{III}}$, $\mathrm{Fe}^{\mathrm{III}}(\mu-\mathrm{OR})\left(\mu-\mathrm{O}_{2}\right) \mathrm{Fe}^{\mathrm{III}}, \mathrm{Fe}^{\mathrm{III}}(\mu-\mathrm{OR})\left(\mu-\mathrm{O}_{2} \mathrm{CR}^{\prime}\right)\left(\mu-\mathrm{O}_{2}\right) \mathrm{Fe}^{\mathrm{III}}$. A legelterjedtebbek a $\mathrm{Fe}^{\mathrm{III}}(\mu-\mathrm{O})\left(\mu-\mathrm{O}_{2}\right) \mathrm{Fe}^{\mathrm{III}}$ szerkezetek, melyek $\mathrm{Fe}^{\mathrm{II}}(\mu-\mathrm{OH})_{2} \mathrm{Fe}^{\mathrm{III}}$ - dioxigén, $\mathrm{Fe}^{\mathrm{III}}(\mu-\mathrm{O})(\mu-\mathrm{OH}) \mathrm{Fe}^{\mathrm{III}}$ $\mathrm{H}_{2} \mathrm{O}_{2}$, valamint $\mathrm{Fe}^{\mathrm{II}}-\mathrm{H}_{2} \mathrm{O}_{2}$ reakciójával állíthatók elő (6. Ábra). Ezek többsége csak alacsony hömérsékleten $\left(\sim 40^{\circ} \mathrm{C} / \mathrm{CH}_{3} \mathrm{CN}, \sim 60^{\circ} \mathrm{C} / \mathrm{CH}_{3} \mathrm{CN}\right)$ generálható, izolálható. Kivételt képez az IndH ligandummal képzett peroxid, amely szobahömérsékleten is képezhető. $\quad \mathrm{Fe}^{\mathrm{III}}\left(\mu-\mathrm{O}_{2}\right) \mathrm{Fe}^{\mathrm{III}}$ összetételü szerkezethez juthatunk $\mathrm{Fe}^{\mathrm{II}}$ prekurzor hidrogénperoxiddal történő reakciójával. PBI és Me-PBI ligandumok esetében az eddig ismert legstabilabb komplexekhez jutottak. Stabilitásuk segédligandumok alkalmazásával (szubsztituált piridinek) tovább nővelhető. A szintézisek során felhasznált ligandumok a 7. ábrán láthatóak. 


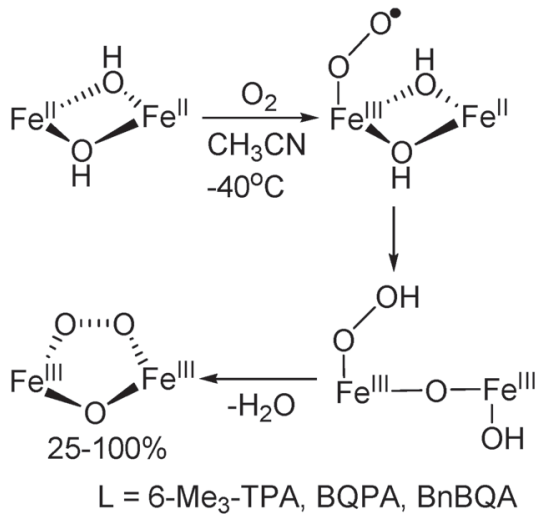

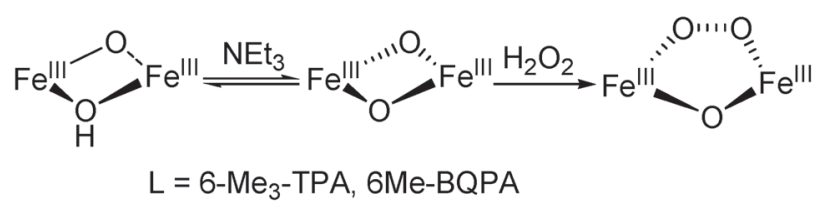

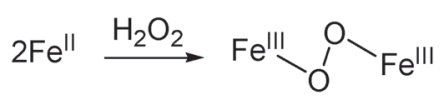

$\mathrm{L}=\mathrm{PB} \mid \mathrm{Me}-\mathrm{PBI}$

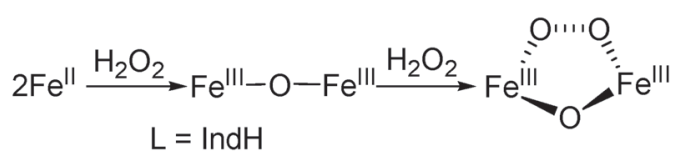

6. Ábra. Néhány irodalmi példa peroxo-divas(III) komplexek előállítására

Az elóállított intermedierekhez az enzimekhez hasonlóan karakterisztikus UV-vis elnyelések és rezonancia-raman rezgések rendelhetök. Ezek alapján, kiegészítve a röntgendiffrakciós mérések eredményeivel (EXAFS, X-ray), számos hasznos információ nyerhető az adott szerkezetre vonatkozóan. Az irodalomban fellelhetö adatokat az 1. Táblázatban tüntettem fel.

Az irodalomban található adatokat elemezve megállapítható, hogy a peroxo-divas(III) komplexekben a vasak közötti távolságot nagymértékben meghatározza, hogy az ionok között milyen hídligandum foglal helyet. A legnagyobb Fe-Fe távolság $(4,01 \quad \AA) \quad$ a $\quad\left[\mathrm{Fe}_{2}\left(\mathrm{HB}\left(3,5-\mathrm{iPr}_{2} \mathrm{pz}\right)_{3}\right)_{2}\right)\left(\mu-\mathrm{O}_{2}\right)$ $\left.\left(\mu-\mathrm{O}_{2} \mathrm{CCH}_{2} \mathrm{C}_{6} \mathrm{H}_{5}\right)_{2}\right]$ komplex esetében figyelhetó meg, ahol a Fe-O-O-Fe egységet két hídhelyzetủ karboxilátcsoport egészít ki. A legkisebb Fe-Fe távolságok $(\sim 3,15 \AA)$ pedig az oxohidas szerkezeteknél találhatók. Általánosságban kijelenthetö, hogy az oxohídak protonálása, illetve alkilezése a Fe Fe távolságok megnövekedésével jár együtt. A szerkezeteket tekintve tehát a kötéstávolság a következő sorrendben növekszik: $\mathrm{Fe}^{\mathrm{III}}(\mu-\mathrm{O})\left(m-\mathrm{O}_{2}\right) \mathrm{Fe}^{\mathrm{III}}<\mathrm{Fe}^{\mathrm{III}}(\mu-\mathrm{OR})\left(\mu-\mathrm{O}_{2} \mathrm{CR}^{\prime}\right)\left(m-\mathrm{O}_{2}\right) \mathrm{Fe}^{\mathrm{III}}<$ $\mathrm{Fe}^{\mathrm{III}}(m-\mathrm{OH})\left(m-\mathrm{O}_{2}\right) \mathrm{Fe}^{\mathrm{III}}$. A $\mathrm{Fe}-\mathrm{Fe}$ kötéshosszakban megmutatkozó különbségek a $\mathrm{n}(\mathrm{O}-\mathrm{O})$ értékekben is megmutatkoznak, értékük lineárisan változik a kötéshossz értékével (8. Ábra), amit elméleti számításokkal is alátámasztottak. Ezen összefüggés alapján a rezonancia-raman adatok birtokában megbecsülhetjük a fémek közötti távolságot, ami nyilván kihatással van mind az intermedier stabilitására, mind a reaktivitására.

Az irodalomban, a peroxo-divas(III) komplexekre fellelhető adatokat összevetve az enzimekre kapott adatokkal, nagyfokú hasonlóságot figyelhetünk meg, ami arra utal, hogy az elöállított vegyületek szerkezetileg jól leírják az enzim aktív centrumában, a fémionok koordinációs övezetében uralkodó viszonyokat.<smiles>[R]c1cccc(CN(Cc2cccc([R])n2)Cc2cccc([R])n2)n1</smiles>

TPA: $\mathrm{R}=\mathrm{H}$; 6-Me - TPA: $R=M e$<smiles>c1ccc(/N=C2\N/C(=N\c3ccccn3)c3ccccc32)nc1</smiles><smiles>c1ccc(-c2nc3ccccc3[nH]2)nc1</smiles>

PBI<smiles>Cc1cccc(CN(C)C2CCCCC2N(C)Cc2cccc(C)n2)n1</smiles>

6-Me $-\mathrm{BPP}$<smiles>Cc1cc(CN(Cc2nc(-c3ccccc3)c(-c3ccccc3)[nH]2)Cc2nc(-c3ccccc3)c(-c3ccccc3)[nH]2)c(O)c(CN(Cc2nc(-c3ccccc3)c(-c3ccccc3)[nH]2)Cc2nc(-c3ccccc3)c(-c3ccccc3)[nH]2)c1</smiles><smiles>CCN=C(P)CN(Cc1nc2ccccc2[nH]1)Cc1nc2ccccc2n1Cc1nc2ccccc2n1CC(O)CN(CC)Cc1nc2ccccc2[nH]1</smiles>

7. Ábra. A peroxo-divas(II) komplexekhez használt ligandumok 
1. Táblázat. Peroxo-divas(III)-tartalmú enzimek és modellvegyületek spektroszkópiai és röntgendiffrakciós adatai

\begin{tabular}{|c|c|c|c|c|}
\hline Peroxo-vegyületek & $\begin{array}{l}\text { UV-vis, } \lambda_{\max }, / \mathrm{nm} \\
\left(\varepsilon, \mathrm{M}^{-1} \mathrm{~cm}^{-1}\right)\end{array}$ & $\begin{array}{l}\text { rRaman } \\
\nu(\mathrm{O}-\mathrm{O})\left(\mathrm{cm}^{-1}\right)\end{array}$ & $\begin{array}{l}\mathrm{r}(\mathrm{Fe}-\mathrm{Fe}) \\
(\AA)\end{array}$ & hivatkozás \\
\hline $\mathrm{hDOHH}_{\text {peroxo }}$ & $630(2800)$ & 855 & 3,44 & [7] \\
\hline sMMO & $725(1800)$ & - & - & {$[11,12]$} \\
\hline$\Delta^{9} \mathrm{D}$ & $700(1100)$ & 898 & - & {$[13,14]$} \\
\hline R2 & $700(1800)$ & 868 & 3,68 & [15] \\
\hline$\left[\mathrm{Fe}_{2}(\mu-\mathrm{O})\left(\mu-\mathrm{O}_{2}\right)\left(6-\mathrm{Me}_{3}-\mathrm{TPA}\right)\right]^{2+}$ & $490(1100) ; 640(1100)$ & 847 & 3,14 & [16] \\
\hline$\left[\mathrm{Fe}_{2}(\mu-\mathrm{O})\left(\mu-\mathrm{O}_{2}\right)(\mathrm{BQPA})\right]^{2+}$ & $480(1000) ; 620(1000)$ & 844 & 3,13 & [17] \\
\hline$\left[\mathrm{Fe}_{2}(\mu-\mathrm{O})\left(\mu-\mathrm{O}_{2}\right)(6-\mathrm{Me}-\mathrm{BQPA})\right]^{2+}$ & $480(1000) ; 620(1000)$ & 853 & 3,15 & [17] \\
\hline$\left[\mathrm{Fe}_{2}(\mu-\mathrm{O})\left(\mu-\mathrm{O}_{2}\right)(\mathrm{BnBQA})\left(\mathrm{CH}_{3} \mathrm{CN}\right)_{2}\right]^{2+}$ & $505(1300) ; 650(1300)$ & 854 & 3,16 & {$[17,18]$} \\
\hline$\left[\mathrm{Fe}_{2}(\mu-\mathrm{OH})\left(\mu-\mathrm{O}_{2}\right)(\mathrm{BnBQA})\left(\mathrm{CH}_{3} \mathrm{CN}\right)_{2}\right]^{3+}$ & $730(2400)$ & 925 & 3,41 & [19] \\
\hline$\left[\mathrm{Fe}_{2}(\mu-\mathrm{O})\left(\mu-\mathrm{O}_{2}\right)(\mathrm{IndH})\right]^{2+}$ & $690(1500)$ & 874 & 3,16 & [20] \\
\hline$\left[\mathrm{Fe}_{2}\left(\mu-\mathrm{O}_{2}\right)(\mathrm{PBI})_{4}\left(\mathrm{CH}_{3} \mathrm{CN}\right)_{2}\right]^{2+}$ & $720(1360)$ & 876 & - & [21] \\
\hline$\left[\mathrm{Fe}_{2}\left(\mu-\mathrm{O}_{2}\right)(\mathrm{Me}-\mathrm{PBI})_{4}\left(\mathrm{CH}_{3} \mathrm{CN}\right)_{2}\right]^{2+}$ & $685(1400)$ & 876 & - & [21] \\
\hline$\left[\mathrm{Fe}_{2}\left(\mathrm{HB}\left(3,5-\mathrm{iPr}_{2} \mathrm{pz}\right)_{3}\right)_{2}\right)\left(\mu-\mathrm{O}_{2}\right)$ & $694(1725)$ & 885 & 4,01 & {$[22,23]$} \\
\hline \multicolumn{5}{|l|}{$\left.\left(\mu-\mathrm{O}_{2} \mathrm{CCH}_{2} \mathrm{C}_{6} \mathrm{H}_{5}\right)_{2}\right]$} \\
\hline$\left[\mathrm{Fe}_{2}(N\right.$-Et-HPTB $\left.)\left(\mu-\mathrm{O}_{2}\right)\left(\mathrm{OPPh}_{3}\right)_{2}\right]$ & $588(1500)$ & 900 & 3,46 & {$[24,25]$} \\
\hline$\left[\mathrm{Fe}_{2}\left(6-\mathrm{Me}_{2}-\mathrm{BPP}\right)_{2}\left(\mu-\mathrm{O}_{2}\right)(\mu-\mathrm{OH})\right]^{+}$ & $644(3000)$ & 908 & 3,40 & [26] \\
\hline$\left[\mathrm{Fe}_{2}\left(6-\mathrm{Me}_{2}-\mathrm{BPP}\right)_{2}\left(\mu-\mathrm{O}_{2}\right)(\mu-\mathrm{O})\right]$ & $577(1500)$ & 847 & 3,17 & [26] \\
\hline$\left[\mathrm{Fe}_{2}(\mathrm{Ph}-\text { bimp })\left(\mu-\mathrm{O}_{2}\right)\left(\mu-\mathrm{O}_{2} \mathrm{CC}_{6} \mathrm{H}_{5}\right)\right]^{2+}$ & $700(1700)$ & 884 & 3,33 & [27] \\
\hline
\end{tabular}

${ }^{\mathrm{a}}$ 6- $\mathrm{Me}_{3}-\mathrm{TPA}=\operatorname{trisz}(6-$ metil-2-piridilmetil)-amin; $\mathrm{BQPA}=\operatorname{bisz}(2-$ kinolilmetil)(2-piridilmetil)-amin; $\mathrm{BnBQA}=N$-benzil- $N, N$-bisz(2-kinolilmetil)-amin; IndH = 1,3-bisz(2'-piridil-imino)-izoindolin; PBI = 2-(2-piridil)-benzimidazol; 3,5-iPr $2 \mathrm{pz}=3,5$-bisz(izopropil)-pirazol; $N$-Et-HPTB $=N$, $N, N$, $N$ '-tetrakisz(1'-etilbenzimidazolil-2'-metil)-2-hidroxi-1,3-diaminopropán); 6- $\mathrm{Me}_{2}$-BPP = bisz(6-metil-2-piridilmetil)-amin; Ph-bimp = 2,6-bisz[bisz[2-(1-metil-4,5-difenilimidazolil)-metil) aminometil]-4-metilfenolát.

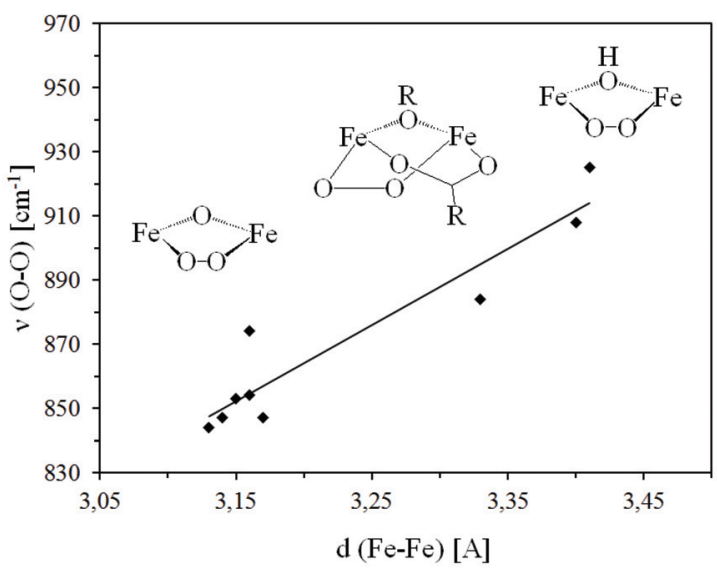

8. Ábra. Összefüggés a szerkezet (EXAFS) és a spektroszkópiai jellemzők (rRaman) között peroxo-divas(III) intermedierekre. ${ }^{17}$

$\mathrm{Az}$ irodalomban a szerkezeti modellek mellett számos funkcionális modell is található. Ezen rendszerek többnyire a peroxo-komplexek képződési és bomlási kinetikáját, valamint reaktivitását írják le.

A funkcionális modellek közül a $\left[(\mathrm{BnBQA}) \mathrm{Fe}^{\mathrm{II}}(\mu-\mathrm{OH})_{2}\right.$ $\left.\mathrm{Fe}^{\mathrm{II}}(\mathrm{BnBQA})\right]^{2+}$-tartalmú rendszert emelném ki, ami nagyon jól modellezi az R2 enzim elemi folyamatait (9. Ábra). A prekurzor komplex dioxigénnel való reakciója a korábban ismertetett $\left[\mathrm{Fe}_{2}(\mu-\mathrm{O})\left(\mu-\mathrm{O}_{2}\right)(\mathrm{BnBQA})\left(\mathrm{CH}_{3} \mathrm{CN}\right)_{2}\right]^{2+}$ intermediert eredményezi $\left(\lambda_{\max }=650 \mathrm{~nm}, t_{1 / 2}=40\right.$ perc $-40^{\circ} \mathrm{C}$-on $)$, amely sztöchiometrikus mennyiségü sav $\left(\mathrm{HClO}_{4} \mathrm{v} . \mathrm{HNO}_{3}\right)$ hatására egy kevésbé stabilis $\left[\mathrm{Fe}_{2}(\mu-\mathrm{OH})\left(\mu-\mathrm{O}_{2}\right)(\mathrm{BnBQA})\left(\mathrm{CH}_{3} \mathrm{CN}\right)_{2}\right]^{2+}$ peroxo formává alakul át $\left(\lambda_{\max }=730 \mathrm{~nm}, t_{1 / 2}=140 \mathrm{~s}-40^{\circ} \mathrm{C}\right.$-on). Ennek exponenciális bomlása $15-20 \%$-os hozammal a vegyes vegyértékü $\left[\mathrm{Fe}^{\mathrm{III}, \mathrm{IV}}{ }_{2}(\mu-\mathrm{O})(\mathrm{BnBQA})\right]^{5+}$ komplexet eredményezi (antiferromágneses csatolt vas(III)/vas(IV) centrum, $\mathrm{S}=1 / 2$ Mössbauer és ESR), amely az R2 enzim esetében az oxidációért felelős reaktív részecskeként $(\mathrm{X})$ került említésre. ${ }^{19}$

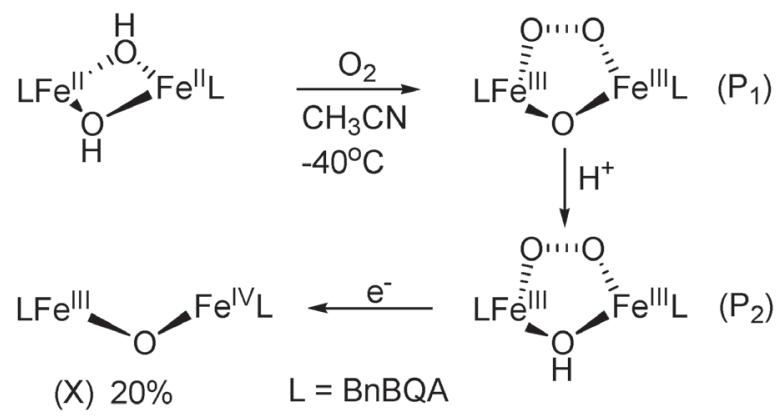

9. Ábra. Szerkezeti és funkcionális R2 modell ${ }^{19}$

Megállapítást nyert, hogy a $\left[(\mathrm{PBI}) \mathrm{Fe}^{\mathrm{III}}\left(\mu-\mathrm{O}_{2}\right) \mathrm{Fe}^{\mathrm{III}}(\mathrm{PBI})\right]^{4+}$ összetételű komplex képződési és bomlási folyamata reverzibilis, valamint hogy a peroxo-komplex bomlása dioxigént eredményez. Ez alapján a vizsgált rendszer a 
kétmagvú kataláz enzimek funkcionális modelljének tekinthetö. $^{21}$

A $\quad\left[\mathrm{Fe}^{\mathrm{II}}(\mathrm{IndH})(\mathrm{MeCN})_{3}\right]\left(\mathrm{ClO}_{4}\right)_{2}$ és $\mathrm{H}_{2} \mathrm{O}_{2}$ reakciója acetonitrilben $\quad\left[\mathrm{Fe}_{2}(\mu-\mathrm{O})\left(\mu-\mathrm{O}_{2}\right)(\mathrm{IndH})_{2}\right]^{2+} \quad$ összetételü komplexet eredményez, amely aktív katalizátornak bizonyult egyes oxigén atom transzfer (OAT) és hidrogén atom transzfer (HAT) folyamatokban. Oxidálószerként hidrogén peroxidot, modellszubsztrátként szubsztituált tioanizol és benzilalkohol származékokat használtak (10. Ábra). ${ }^{20}$

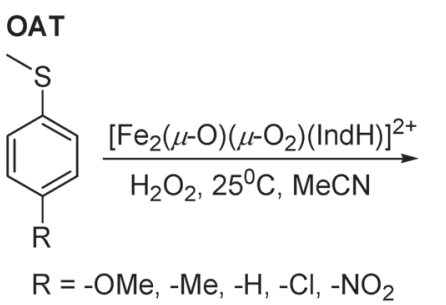<smiles>[R]c1ccc(S(C)=O)cc1</smiles>

\section{HAT}

$$
\underset{R=-O M e,-M e,-H,-C l,-\mathrm{NO}_{2}}{\frac{\left[\mathrm{Fe}_{2}(\mu-\mathrm{O})\left(\mu-\mathrm{O}_{2}\right)(\mathrm{IndH})\right]^{2+}}{\mathrm{H}_{2} \mathrm{O}_{2}, 25^{\circ} \mathrm{C}, \mathrm{MeCN}}}
$$<smiles>[R]c1ccc(C=O)cc1CC</smiles>

10. Ábra. $\left[\mathrm{Fe}_{2}(\check{e}-\mathrm{O})\left(\check{e}-\mathrm{O}_{2}\right)(\mathrm{IndH})_{2}\right]^{2+}$-katalizált OAT és HAT folyamatok ${ }^{20}$

A részletes reakciókinetikai vizsgálatok során a szubsztituált szubsztrátokra kapott Hammett összefüggések mindkét esetben negatív $\rho$ értéket eredményeztek ( $\rho=-0,4$ és $-0,85)$, amely értékek alapján az oxidációért felelős részecskéhez elektrofil karakter társítható (11. Ábra). Mivel a peroxidok nukleofil karakterüek, ezért feltételezhetö hogy a fenti HAT és OAT folyamatok $\mathrm{Fe}^{\mathrm{IV}} \mathrm{O}$ intermedieren keresztül játszódnak le. ${ }^{20}$

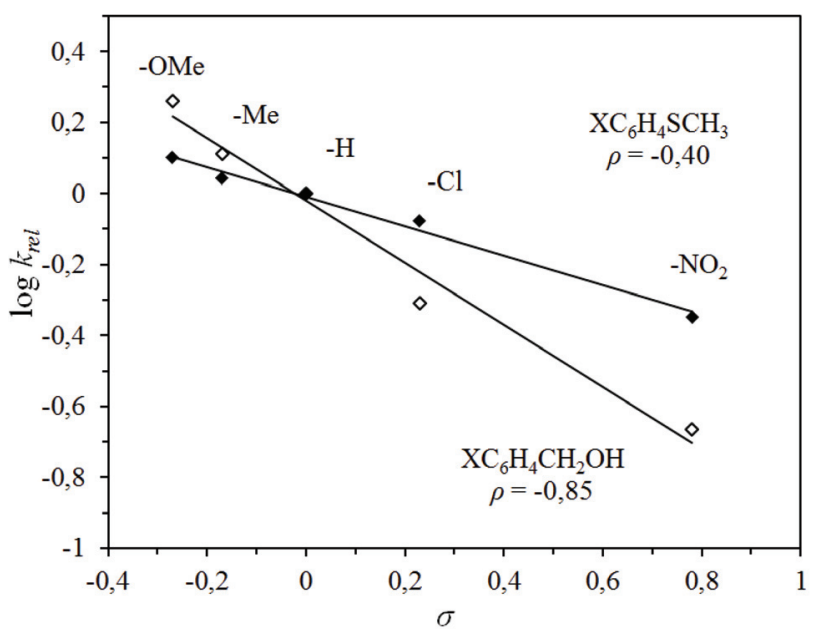

11. Ábra. $\mathrm{A}\left[\mathrm{Fe}_{2}(\mu-\mathrm{O})\left(\mu-\mathrm{O}_{2}\right)(\mathrm{IndH})_{2}\right]^{2+}$-katalizált OAT és HAT folyamatok esetében kapott Hammett összefüggések. ${ }^{20}$
A benzilalkohol oxidációja során észlelt kinetikus izotóp effektus értéke $(K I E=9,1)$ alapján valószínüsíthető, hogy a hidrogén atom transzfer a sebesség-meghatározó lépésben megy végbe (12. Ábra).

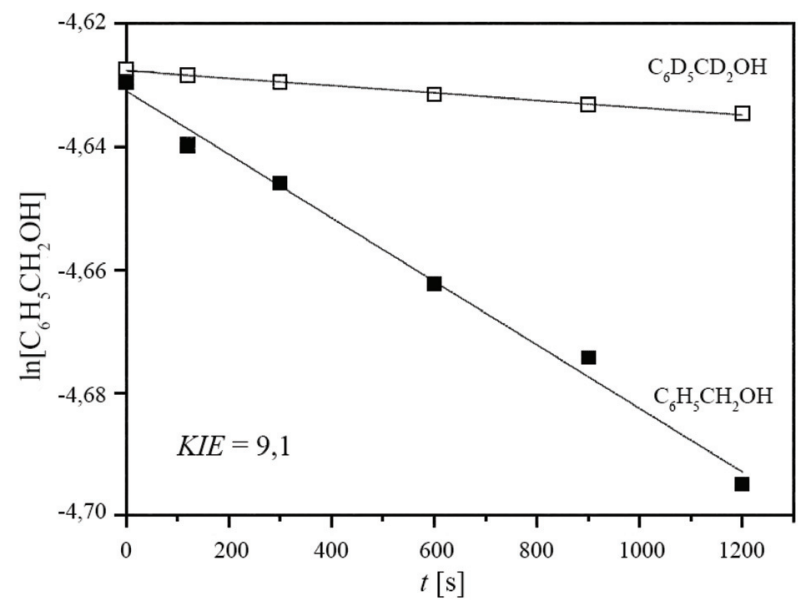

12. Ábra. $\mathrm{A}\left[\mathrm{Fe}_{2}(\mu-\mathrm{O})\left(\mu-\mathrm{O}_{2}\right)(\mathrm{IndH})_{2}\right]^{2+}$-katalizált HAT folyamatok esetében észlelt kinetikus izotóp effektus $(K I E)$.

A szubsztituált tioanizol származékok esetében a sebességeket a redoxipotenciálok függvényében ábrázolva az egyenes meredeksége -0,8-nak adódott, amely alapján kijelenthetjük, hogy a folyamat direkt oxigén transzferen keresztül játszódik le, az elektrontranszfer, mint lehetséges részlépés kizárható (13. Ábra).

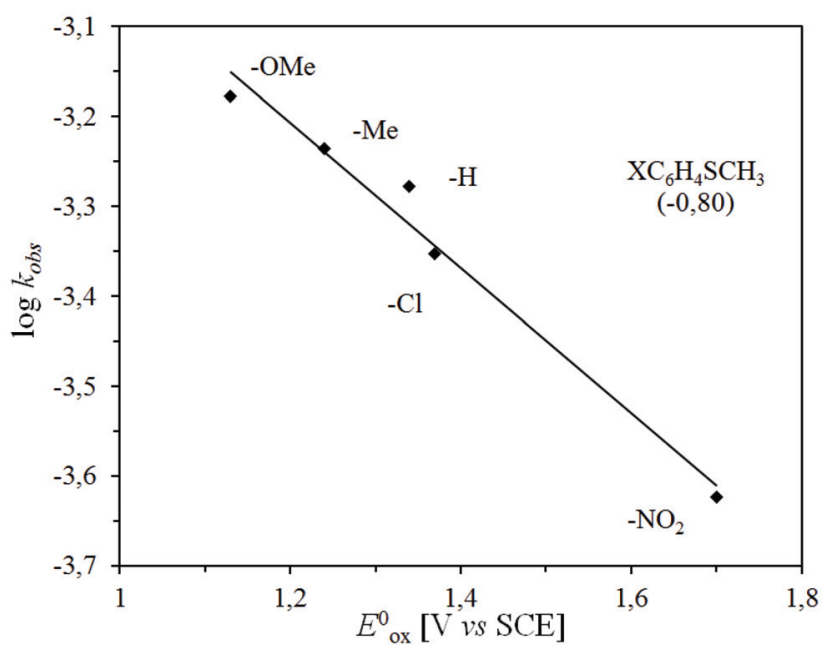

13. Ábra. A redoxi potenciál és a reakciósebességi állandók közötti összefüggés a $\left[\mathrm{Fe}_{2}(\mu-\mathrm{O})\left(\mu-\mathrm{O}_{2}\right)(\mathrm{IndH})_{2}\right]^{2+}$-katalizált OAT folyamatra. ${ }^{20}$

\section{Köszönetnyilvánítás}

A kutatás az Országos Tudományos Kutatási Alapprogram (OTKA K108489), és a Bolyai János Kuratórium (MTA) finanszírozásával valósult meg. 


\section{Hivatkozások}

1. Costas, M.; Mehn, M. P.; Que, L., Jr. Chem. Rev. 2004, 104, 939. https://doi.org/10.1021/cr020628n

2. Du Bois, Mizoguchi, T. J.; Lippard, S. J. Coord. Chem. Rev. 2000, 202-204, 443.

https://doi.org/10.1016/S0010-8545(00)00336-2

3. Stubbe, J.; van der Donk, W. Chem. Rev. 1998, 98, 705.

https://doi.org/10.1021/cr9400875

4. Lindqvist, Y.; Huang, W.; Schneider, G.; Shanklin, J. EMBOJ. 1996, 15, 4081.

5. Rosenzweig, A. C.; Lippard, S. J. Acc. Chem. Res. 1994, 27, 229. https://doi.org/10.1021/ar00044a003

6. Rosenzweig, A. C.; Nordlund, P.; Takahara, P. M.; Frederick, C. A.; Lippard, S. J. Chem. Biol. 1995, 2, 409. https://doi.org/10.1016/1074-5521(95)90222-8

7. Han, Z.; Sakai, N.; Böttger, L. H.; Klinke, S.; Hauber, J.; Trautwein, A. X.; Hilgenfeld, R. Structure 2015, 23, 1. https://doi.org/10.1016/j.str.2014.12.001

8. Vu, V. V.; Emerson, J. P.; Martinho, M.; Kim, Y. S.; Münck, E.; Park, M. H.; Que, L., Jr. PNAS 2009, 106, 14814. https://doi.org/10.1073/pnas.0904553106

9. Stenkamp, R. E. Chem. Rev. 1994, 94, 715 https://doi.org/10.1021/cr00027a008

10. Wilkins, P. C.; Wilkins, R. G. Coord. Chem. Rev. 1987, 79, 195. https://doi.org/10.1016/0010-8545(87)80003-6

11. Liu, K. E.; Valentine, A. M.; Wang, D.; Huynh, B. H.; Edmondson, D. E.; Salifoglou, A.; Lippard, S. J. J. Am. Chem. Soc. 1995, 117, 10714.

12. Valentine, A. M., Stahl, S. S.; Lippard, S. J. J. Am. Chem. Soc. 1999, 121, 3876. https://doi.org/10.1021/ja9839522

13. Broadwater, J. A.; Ai, J.; Loehr, T. M.; Sanders, L.; Fox, B. G. Biochemistry 1998, 37, 14664. https://doi.org/10.1021/bi981839i

14. Broadwater, J. A.; Achim, C.; Münck, E.; Fox, B. G. Biochemistry 1999, 38, 12197.

https://doi.org/10.1021/bi9914199

15. Skulan, A. J.; Brunold, T. C.; Baldwin, J.; Saleh, L.; Bollinger, J. M.; Solomon, E. I. J. Am. Chem. Soc. 2004, 126, 8842. https://doi.org/10.1021/ja049106a

16

\section{Structural and functional models of non-heme diiron oxidoreductases}

Metalloenzymes with non-heme diiron centers have emerged as important class of enzymes. Several members of them are now structurally characterized. The following review summarizes recent investigations with non-heme diiron oxidoreductases (Ribonucleotide reductase (R2), soluble methane monooxygenase (sMMO), stearoyl-acyl carrier protein (ACP) $\Delta^{9}$-desaturase $\left(\Delta^{9} \mathrm{D}\right)$, human deoxyhypusine hydroxylase $(\mathrm{hDOHH})$ and hemerythrin $(\mathrm{Hr})$, via their synthetic models focusing specifically on the synthesis, characterization, and spectral behavior of well-defined peroxo-diiron(III) intermediates. Fundamental biochemical processes are catalyzed by these enzymes, such as biodegradation of hydrocarbons, or synthesis of essential biomolecules including DNA building blocks. Better understanding on biologically determinant reactions may lead scientists to the discovery of crucial drugs and even "green solutions" in industrial applications. A brief overview on reaction kinetics, that has afforded useful insights into the mechanism of dioxygen activation and substrate oxidation by diiron centers, is also included in this paper.
Dong, Y. H.; Zang, Y.; Shu, L. J.; Wilkinson, E. C.; Que, L., Jr.; Kauffmann, K.; Münck, E. J. Am. Chem. Soc. 1986, 108, 5027. https://doi.org/10.1021/ja00276a065

17. Fiedler, A. T.; Shan, X.; Mehn, M. P.; Kaizer, J.; Torelli, S.; Frisch, J. R.; Kodera, M.; Que, L., Jr. J. Phys. Chem. 2008, 112, 13037. https://doi.org/10.1021/jp8038225

18. Kryatov, S. V.; Taktak, S.; Korendovych, I. V.; Rybak-Akimova, E. V.; Kaizer, J.; Torelli, S.; Shan, X.; Mandal, S.; MacMurdo, V. L.; i Payeras, A. M.; Que, L., Jr. Inorg. Chem. 2005, 44, 85. https://doi.org/10.1021/ic0485312

19. Cranswick, M. A.; Meier, K. K.; Shan, X.; Stubna, A.; Kaizer, J.; Mehn, M. P.; Münck, E.; Que, L., Jr. Inorg. Chem. 2012, 51, 10417. https://doi.org/10.1021/ic301642w

20. Pap, J. S.; Cranswick, M. A.; Balogh-Hergovich, É.; Baráth, G.; Giorgi, M.; Rohde, G. T.; Kaizer, J.; Speier, G.; Que, L., Jr. Eur. J. Inorg. Chem. 2013, 3858. https://doi.org/10.1002/ejic.201300162

21. Pap, J. S.; Draksharapu, A.; Giorgi, M.; Browne, W. R.; Kaizer, J.; Speier, G. Chem. Commun. 2014, 50, 1326. https://doi.org/10.1039/C3CC48196D

22. Kim, K.; Lippard, S. J. J. Am. Chem. Soc. 1996, 118, 4914. https://doi.org/10.1021/ja9604370

23. Brunold, T. C.; Tamura, N.; Kitajima, M.; Moro-oka, Y.; Solomon, E. I. J. Am. Chem. Soc. 1998, 120, 5674. https://doi.org/10.1021/ja980129x

24. Dong, Y.; Yan, S.; Young, V. G., Jr.; Que, L., Jr. Angew. Chem., Int. Ed. Engl. 1996, 35, 618. https://doi.org/10.1002/anie.199606181

25. Dong, Y.; Ménage, S.; Brennan, B. A.; Elgren, T. E.; Jang, H. G.; Pearce, L. L.; Que, L., Jr. J. Am. Chem. Soc. 1993, 115,1851 . https://doi.org/10.1021/ja00058a033

26. Zhang, X.; Furutachi, H.; Fujinami, S.; Nagatomo, S.; Maeda, Y.; Watanabe, Y.; Kitagawa, T.; Suzuki, M. J. Am. Chem. Soc. 2005, 127, 826. https://doi.org/10.1021/ja045594a

27. Ookubo, T.; Sugimoto, H.; Nagayama, T.; Masuda, H.; Sato, T.; Tanaka, K.; Maeda, Y.; Okawa, H.; Hayashi, Y.; Uehara, A.; Suzuki, M. J. Am. Chem. Soc. 1996, 118, 701. https://doi.org/10.1021/ja953705n
Synthetic diiron complexes are often investigated as structural models of active centers in the title enzymes. They are proved to have the potential to catalyze the oxidation of alkanes, alcohols, sulfides in the presence of atmospheric dioxygen, or various peroxides. Highly reactive, short lived oxygen-species have been identified as responsible particles for most biochemical transformations. Typical forms of these intermediates can be described by the following general structures: $\mathrm{Fe}^{\mathrm{III}}\left(\mu-\mathrm{O}_{2}\right) \mathrm{Fe}^{\mathrm{III}}$; $\mathrm{Fe}^{\mathrm{III}}(\mu-\mathrm{O})\left(\mu-\mathrm{O}_{2}\right) \mathrm{Fe}^{\mathrm{III}}, \quad \mathrm{Fe}^{\mathrm{III}}(\mu-\mathrm{OH})\left(\mu-\mathrm{O}_{2}\right) \mathrm{Fe}^{\mathrm{III}}, \quad \mathrm{Fe}^{\mathrm{III}}(\mu-\mathrm{OR})$ $\left(\mu-\mathrm{O}_{2}\right) \mathrm{Fe}^{\mathrm{III}}, \mathrm{Fe}^{\mathrm{III}}(\mu-\mathrm{OR})\left(\mu-\mathrm{O}_{2} \mathrm{CR}^{\prime}\right)\left(\mu-\mathrm{O}_{2}\right) \mathrm{Fe}^{\mathrm{III}}$. Early results in this subject showed that high valent oxidation states of oxo-, peroxo complexes could be maintained only at extreme conditions $\left(-40-60^{\circ} \mathrm{C}\right.$, specific organic solvents). Fortunately, advances in ligand design and synthesis have improved the lifespan. By fine tuning bi-, tri- and tetradentate $N$-donor ligands the iron-oxygen species have become observable and identifiable by all spectroscopic methods at room temperature as well. Oxygen donor ligands (carboxylates, alcohols) are less favored, however they are widespread in enzymes. In models, the electron rich $\mathrm{N}$-donor environment has the advantage of flexible electron 
adjustment in the iron centered N-Fe-O system. Both organic and inorganic peroxides are suitable for synthesis. Usually, a precursor complex (in the form of a mononuclear $\mathrm{Fe}^{\mathrm{II}}$ ) is converted to an oxo-bridged $\mathrm{Fe}^{\mathrm{III}}$ complex. The bridge moiety strongly determines reactivity. By analyzing literature data it can be concluded that in peroxodiiron(III) complexes reactivity depends on the Fe-Fe distance that is naturally regulated by the corresponding bridge ligand. Concerning the extremes: highest $\mathrm{Fe}-\mathrm{Fe}$ distance $(4,01 \AA)$ was observed in a double carboxylate-bridged

$\left[\mathrm{Fe}_{2}\left(\mathrm{HB}\left(3,5-\mathrm{iPr} \mathrm{pz}_{3}\right)_{2}\right)\left(\mu-\mathrm{O}_{2}\right)\left(\mu-\mathrm{O}_{2} \mathrm{CCH}_{2} \mathrm{C}_{6} \mathrm{H}_{5}\right)_{2}\right] \quad$ complex. The shortest $\mathrm{Fe}-\mathrm{Fe}$ distance was generated by a $m-\mathrm{O}$ bridge. Generally, protonation of oxo-bridges and alkylation increase bond distance. The sequence is as follows: $\mathrm{Fe}^{\mathrm{III}}(\mu-\mathrm{O})\left(\mu-\mathrm{O}_{2}\right) \mathrm{Fe}^{\mathrm{III}}$ $<\mathrm{Fe}^{\mathrm{III}}(\mu-\mathrm{OR})\left(\mu-\mathrm{O}_{2} \mathrm{CR}^{\prime}\right)\left(\mu-\mathrm{O}_{2}\right) \mathrm{Fe}^{\mathrm{III}}<\mathrm{Fe}^{\mathrm{III}}(\mu-\mathrm{OH})\left(\mu O_{2}\right) \mathrm{Fe}^{\mathrm{III}}$. Various values of Raman $\mathrm{n}(\mathrm{O}-\mathrm{O})$ vibrations can confirm the differences in bond distances, furthermore articles often include theoretical quantum chemical calculations in order to support experimental data. Mössbauer spectroscopy, X-ray crystallography and EXAFS are widely used for the same purpose. Peroxodiiron(III) complexes are considered good structural models by adequately mimicking the coordination sphere in the active center of the corresponding enzyme.

In contrast with the above strategy functional modelling requires chemical approach. There is less focus on structural similarity. Mostly, the formation and self-decay of peroxo-complexes is investigated. As an example, the $\left[(\mathrm{BnBQA}) \mathrm{Fe}^{\mathrm{II}}(\mu-\mathrm{OH})_{2} \mathrm{Fe}^{\mathrm{II}}(\mathrm{BnBQA})\right]^{2+}$ complex can be mentioned here. The reaction of this precursor state with dioxygen results in a $\left[\mathrm{Fe}_{2}(\mu-\mathrm{O})\left(\mu-\mathrm{O}_{2}\right)(\mathrm{BnBQA})\left(\mathrm{CH}_{3} \mathrm{CN}\right)_{2}\right]^{2+}$ form that can be transformed into an unstable $\left[\mathrm{Fe}_{2}(\mu-\mathrm{OH})\left(\mu-\mathrm{O}_{2}\right)(\mathrm{BnBQA})\left(\mathrm{CH}_{3} \mathrm{CN}\right)_{2}\right]^{2+}$ with stoichiometric amount of acid $\left(\mathrm{HClO}_{4}\right.$ v. $\left.\mathrm{HNO}_{3}\right)$. The active species was identified as a mixed-valent $\left[\mathrm{Fe}^{\mathrm{III}, \mathrm{IV}}{ }_{2}(\mu-\mathrm{O})(\mathrm{BnBQA})\right]^{5+}$ complex responsible for oxidation in functional $\mathrm{R} 2$ enzyme mimicking reactions.

The reactivity of active intermediates is often tested by small organic substrates (thioanisole, benzyl alcohol) in oxygen atom transfer (OAT), or hydrogen atom transfer (HAT) reactions. Characteristic changes in UV-Vis spectra can be followed by time-based measurements as is was done with $\left[\mathrm{Fe}^{\mathrm{II}}(\mathrm{IndH})(\mathrm{MeCN})_{3}\right]\left(\mathrm{ClO}_{4}\right)_{2}$. Hammett constants, calculated by the use of para-substituted substrates, revealed the short presence of an $\mathrm{Fe}^{\mathrm{IV}} \mathrm{O}$ intermediate involved in the oxidation. Labelled, non-radioactive heavy-atoms (D, $\left.{ }^{18} \mathrm{O}\right)$ have been successfully applied for the determination of kinetic isotope effect $(K I E)$. The KIE value is an important information on the nature of the rate-limiting step in the mechanism. During the oxidation of benzyl alcohol $(K I E=9.1)$ catalyzed by $\left[\mathrm{Fe}_{2}(\mu-\mathrm{O})\left(\mu-\mathrm{O}_{2}\right)(\mathrm{IndH})_{2}\right]^{2+}$ hydrogen atom transfer happens in the rate-limiting step. Thioanisole oxidation catalyzed by the same intermediate has been found to be a direct oxygen transfer reaction determined by the correlation between redox potentials and rate constants.

The final aim of reaction kinetics is the discovery of an exact enzyme mechanism. Based on the results summarized in this article, an explicit challenge for the future is the design of new catalysts that are able to use dioxygen or peroxides for efficient and selective oxidation reactions that can be exploited in both pharmacology and several industrial area. 